Animal, Poultry and Fish Production Research

\title{
EFFECT OF SUPPLEMENTAL ZINC AND COPPER ON PERFORMANCE
} OF GROWING RABBITS

\author{
Amera A.A. Helal", O.M. AbdEl-Monam, A.E. Naser and M.S. Ayyat \\ Anim. Prod. Dept., Fac. Agric., Zagazig Univ., Egypt
}

Received: 19/11/2017 ; Accepted: 06/12/2017

\begin{abstract}
Forty-two New Zealand White male rabbits with average body weight 546.74 g were randomly assigned to 7 groups (6 animals in each) in a completely randomized design to study the effect of dietary zinc supplementation through inorganic $(\mathrm{ZnO})$ or organic (Zinc EDTA) sources in combinations with copper $\left(\mathrm{CuSO}_{4}\right)$ on growth performance. Rabbits of the first group (T1) were given basal diet without any supplementations (control group), while the other 6 groups were given basal diet containing zinc and copper as follows: group 2 (T2) received basal diet $+250 \mathrm{mg} \mathrm{Cu} / \mathrm{kg}$ diet from $\mathrm{CuSo}_{4}$, group 3 (T3) received basal diet $+500 \mathrm{mg} \mathrm{Cu} / \mathrm{kg}$ diet, group 4 (T4) received basal diet +20 $\mathrm{mg} \mathrm{Zn}$ from Zinc EDTA $+250 \mathrm{mg} \mathrm{Cu} / \mathrm{kg}$ diet, group 5 (T5) received basal diet $+20 \mathrm{mg} \mathrm{Zn}$ from Zinc $\mathrm{EDTA}+500 \mathrm{mg} \mathrm{Cu} / \mathrm{kg}$ diet, group 6 (T6) received basal diet $+20 \mathrm{mg} \mathrm{Zn}$ from $\mathrm{ZnO}+250 \mathrm{mg} \mathrm{Cu} / \mathrm{kg}$ diet and group 7 (T7) received basal diet $+20 \mathrm{mg} \mathrm{Zn}$ from $\mathrm{ZnO}+500 \mathrm{mg} \mathrm{Cu} / \mathrm{kg}$ diet, respectively. Live body weight, daily body gain, daily feed intake and feed conversion ratio were significantly increased by feeding rabbits on diets supplemented with 250 or $500 \mathrm{mg} \mathrm{Cu} / \mathrm{kg}$ diet. More enhancements were recorded in rabbits fed with $20 \mathrm{mg}$ zinc as $\mathrm{ZnO}$ and $250 \mathrm{mg}$ copper (T6). Total protein concentration in blood serum was significantly increased in rabbits fed $20 \mathrm{mg} \mathrm{Zn}$ from $\mathrm{Zn}$ EDTA $+500 \mathrm{mg} \mathrm{Cu} / \mathrm{kg}$ diet (T5). Also the same treatment increased ceriatenine (CREAT) concentration in blood serum. While, $\mathrm{Cu}$ supplementations at 250 (T2) or 500 (T3) $\mathrm{mg} / \mathrm{kg}$ feed increased urea concentration. All supplementation treatments significantly increased pre-slaughter weight comparing to un-supplemented control rabbits. The highest pre-slaughter weight was found in rabbits fed with diet containing $250 \mathrm{mg} \mathrm{Cu} / \mathrm{kg}$ diet (T2) or with $20 \mathrm{mg} \mathrm{Zn}$ from $\mathrm{ZnO}+250 \mathrm{mg} \mathrm{Cu} / \mathrm{kg}$ diet (T6). Weights of carcass, liver and kidney and dressing (\%) as well as weights of head and hind part did not significantly affected with the tested supplementations. Economically final margin was increased in all rabbits fed supplemented feed. The highest income from gain and the highest final margin were recorded in rabbit groups fed diet supplemented with $250 \mathrm{mg} \mathrm{Cu} / \mathrm{kg}$ diet (T2) or $20 \mathrm{mg}$ $\mathrm{Zn}$ from $\mathrm{ZnO}+250 \mathrm{mg} \mathrm{Cu} / \mathrm{kg} \operatorname{diet}(\mathrm{T} 6$ ).
\end{abstract}

Key words: Rabbits, zinc, copper, growth performance, blood analysis, carcass components, economic efficiency.

\section{INTRODUCTION}

The livestock sector globally is highly dynamic. In developing countries, it is evolving in response to rapidly increasing demand for livestock products. In developed countries, demand for livestock products is stagnating, while many production systems are increasing their efficiency and environmental sustainability. Historical changes in the demand for livestock

\footnotetext{
* Corresponding author: Tel. : +201095950678

E-mail address: helalamera@yahoo.com
}

products have been largely driven by human population growth, income growth and urbanization and the production response in different livestock systems has been associated with science and technology as well as increases in animal numbers (Thornton, 2010).

Life on earth has evolved within a complex mixture of organic and inorganic compounds. While organic molecules such as amino acids, carbohydrates and nucleotides form the 
backbone of proteins, these fundamental components of macromolecules are enzymatically synthesized and ultimately degraded. Inorganic elements, such as copper and zinc, once solubilized from the earth's crust, are neither created nor destroyed and therefore their homeostatic regulation is under strict control. In the fascinating field of metals in biology, by virtue of direct interactions with amino acid side-chains within polypeptide chains, metals play unique and critical roles in biology, promoting structures and chemistries that would not otherwise be available to proteins alone (Festa and Thiel, 2011).

Trace elements, though required in minute quantities are essential for maintaining health and immunity. They are involved in growth, production and reproduction. Trace elements act as cofactors of enzymes which are important to the immunity of animal (Aksu et al., 2012). Superoxide dismutase, glutathione reductase, glutathione peroxidase, thioredoxin reductase, ceruloplasmin and catalase are important enzymes that have trace elements as cofactors. These enzymes act as antioxidants and prevent oxidative stress by eutralizing oxidants produced under different stresses. Besides, trace elements contribute to general health of animal thereby enhancing disease resistance. Trace elements are important for proper functioning of a number of enzymes and proteins which are involved in many physiological, biochemical and metabolic processes that contribute to growth and production (Yatoo et al., 2013). Overall, trace elements improve immune competence and productive performance (Terpilowska and Siwicki, 2011).

Copper and zinc are antagonists, and the balance between them is an example of biological dualism. This does that, and that does this, and they often fight with each other. Both minerals play important roles in the body. Balancing copper $(\mathrm{Cu})$ and zinc $(\mathrm{Zn})$, though vitally important, may not be as easy as expected. Copper is an essential constituent of the growing number of cuproenzymes and copper metalloprotein with functions as diverse as electron transfer (Cobine et al., 2006 ; Festa and Thiel, 2011), pigmentation (Sendovski et al., 2011; Xu et al., 2013) and oxidation resistance (Wang et al., 2013; Ladomersky and Petris, 2015).

Ayyat and Marai (2000) reported that supplementing rabbits with 100,200 or $300 \mathrm{Zn}$ $\mathrm{mg} / \mathrm{kg}$ diet significantly increased live weight gains, but had no effect on feed intake, feed conversion ratio compared to control animals or those fed $400 \mathrm{Zn} \mathrm{mg} / \mathrm{kg}$ diet. Adequate zinc positively affects feed utilization through participating in the metabolism of carbohydrates, lipids, and proteins (McDonald, 2000).

So, the present work was conducted to study the combined effect of dietary zinc and copper supplementation on growth performance, feed efficiency and carcass composition of male rabbits.

\section{MATERIALS AND METHODS}

Such experiment was carried out in Animal Production Department, Faculty of Agriculture, Zagazig University, Egypt, during the period from November to January (duration of the experimental period of 8 weeks) to study the effect of dietary zinc supplementation through inorganic ( $\mathrm{ZnO})$ or organic (Zinc EDTA) sources in combination with copper $\left(\mathrm{CuSo}_{4}\right)$ on growth performance of male New Zealand White rabbits (NZW).

Forty-two New Zealand White male rabbits with average body weight of $546.74 \mathrm{~g}$ were randomly assigned to 7 groups (6 animals in each) in a completely randomized design. Rabbits of the first group (T1) were given basal diet without any supplementations (control group), while the other 6 groups were given basal diet containing zinc and/ or copper as follows: group 2 (T2) received basal diet +250 $\mathrm{mg} \mathrm{Cu} / \mathrm{kg}$ diet from $\mathrm{CuSo}_{4}$, group 3 (T3) received basal diet $+500 \mathrm{mg} \mathrm{Cu} / \mathrm{kg}$ diet, group 4 (T4) received basal diet $+20 \mathrm{mg} \mathrm{Zn}$ from Zinc EDTA $+250 \mathrm{mg} \mathrm{Cu} / \mathrm{kg}$ diet, group 5 (T5) received basal diet $+20 \mathrm{mg} \mathrm{Zn}$ from Zinc EDTA + $500 \mathrm{mg} \mathrm{Cu} / \mathrm{kg}$ diet, group 6 (T6) received basal diet $+20 \mathrm{mg} \mathrm{Zn}$ from $\mathrm{ZnO}+250$ $\mathrm{mg} \mathrm{Cu} / \mathrm{kg}$ diet and group 7 (T7) received basal diet $+20 \mathrm{mg} \mathrm{Zn}$ from $\mathrm{ZnO}+500 \mathrm{mg} \mathrm{Cu} / \mathrm{kg}$ diet, respectively. 
Basal diet was as pellets contained $17 \%$ yellow corn, $35 \%$ clover hay, $10 \%$ barley, $13 \%$ soybean meal, $21 \%$ wheat bran, $3.0 \%$ molasses, $0.20 \%$ sodium chloride, $0.40 \%$ vitamins and minerals and $0.40 \%$ limestone. These components were reflected as $88 \%$ organic matter, $17.3 \%$ crude protein, $13.42 \%$ crude fiber, $2.89 \%$ ether extract, $54.39 \%$ nitrogen free extract and $12 \%$ ash. Additionally, Oxide zinc was used as a source of mineral $\mathrm{Zn}$ while EDTA Zinc $\left(\mathrm{C}_{10} \mathrm{H}_{12} \mathrm{~N}_{2} \mathrm{Na}_{2} \mathrm{Zn}\right.$.2H2O) was used for organic zinc supplementations. Copper sulfate was used as a source for Copper.

All animals were kept under similar managerial and hygienic conditions, during the experimental period. The rabbits were raised in cages provided with feeders and automatic nipple drinkers. The building was naturally ventilated and provided with electric fans. Feed consumption was recorded during the experimental period and feed conversion was calculated. Animal body weight (g) was measured at the beginning of the experiment, at $4^{\text {th }}$ week and at the end of the trial. Also, daily body weight gain and feed conversion ratio (Feed intake / body weight gain) were calculated at $4^{\text {th }}$ and $8^{\text {th }}$ week.

At the end of the experimental period, three rabbits were chosen randomly from each group and sacrificed. After complete bleeding, pelt, viscera and tail were removed and the carcass and some carcass components (fore, intermediate and hind parts, liver and head), were weighed. Blood samples of rabbits were collected during slaughter. Serum samples were obtained by centrifugation of blood at $3000 \mathrm{rpm}$ for 20 minutes and kept at $-20^{\circ} \mathrm{C}$ for analyses. Serum total proteins, albumin, creatinine, Urea$\mathrm{N}$ and tranaminase enzymes were determined using commercial kits.

Economic evaluation was calculated according to Ayyat (1991) using the following equation, final margin (Profit) $=$ Income from body gain weight - feed cost. Other overhead costs were assumed constant. Price of one $\mathrm{kg}$ of basal diet was 3 LE (Egyptian pound 0.057 US\$) and price of selling of one $\mathrm{kg}$ live body weight of rabbits was $27 \mathrm{LE}$. Additionally, price of one $\mathrm{kg}$ of feed supplemented with $250 \mathrm{mg} \mathrm{Cu}$ was $3.175 \mathrm{LE}$, price of one $\mathrm{kg}$ of feed supplemented with 500 $\mathrm{mg} \mathrm{Cu}$ was $3.351 \mathrm{LE}$, price of one $\mathrm{kg}$ of feed supplemented with $20 \mathrm{mg}$ Zn from Zn EDTA and $250 \mathrm{mg} \mathrm{Cu}$ was $3.195 \mathrm{LE}$, price of one $\mathrm{kg}$ of feed supplemented with $20 \mathrm{mg} \mathrm{Zn}$ from $\mathrm{Zn}$ EDTA and $500 \mathrm{mg} \mathrm{Cu}$ was $3.371 \mathrm{LE}$, price of one $\mathrm{kg}$ of feed supplemented with $20 \mathrm{mg} \mathrm{Zn}$ from $\mathrm{ZnO}$ and $250 \mathrm{mg} \mathrm{Cu}$ was $3.178 \mathrm{LE}$ and price of one $\mathrm{kg}$ of feed supplemented with 20 $\mathrm{mg} \mathrm{Zn}$ from $\mathrm{ZnO}$ and $500 \mathrm{mg} \mathrm{Cu}$ was 3.354 LE.

Data of the trial was statistically analyzed using one-way ANOVA analysis of SPSS Program (Version 20). Resulted data of growth performance, blood components and preslaughter live body weight were analyzed using analysis of variance, according to the following model:

$Y_{i k}=\mu+T_{i}+e_{i k}$, Where: $Y_{i k}=$ an observation, $\mu$ is the overall mean, $\mathrm{T}$ is the fixed effect treatments $(i=1 \ldots 7)$, and $e_{i k}$ is random error. The data of slaughter traits were statistically analyzed by analysis of covariance according to the following Model 2: $\mathrm{Y}_{\mathrm{ij}}=\mu+\mathrm{T}_{\mathrm{i}}+\mathrm{b}(\mathrm{X}-\mathrm{x})+$ $\mathrm{e}_{\mathrm{ij}}$, where, Yijk, $\mu, \mathrm{T}_{i}$, and $\mathrm{e}_{\mathrm{ij}}$ were as defined in the Model $1, b=$ partial linear regression coefficients of $\mathrm{Y}_{\mathrm{ij}}$ on slaughter weight, $\mathrm{X}=$ value of slaughter weight and $\mathrm{x}=$ overall average of slaughter weight. Significant differences between treatments were tested with Duncan's multiple range test (Duncan, 1955).

\section{RESULTS AND DISCUSSION}

\section{Growth and Feed Performance}

Live body weight (at 4 and 8 weeks) and daily body gain were affected significantly $(\mathrm{P}<$ 0.001 ) by the experimental treatments (Table 1). Feeding rabbits on diets supplemented with 250 or $500 \mathrm{mg}$ copper $/ \mathrm{kg}$ diet, significantly increased final body weight and daily gain as compared to control group. Final body weight increased by 35.97 and $31.08 \%$ in rabbits fed diet supplemented with 250 or $500 \mathrm{mg}$ copper, respectively, when compared with the control group. The same figures for the total daily gain (0-8 weeks of the experimental period) were 47.80 and $42.85 \%$, respectively. On the other hand, rabbits fed diet supplemented with $20 \mathrm{mg}$ zinc as zinc oxide and supplemented with 250 mg copper recorded higher final body weight and growth rate (39.83 and $51.49 \%$, respectively) than the control group. Rabbit group fed diets 
Helal, et al.

Table 1. Live body weight and gain of New Zealand White male rabbits as affected by zinc and copper supplementation (Mean $\pm \mathrm{SE}$ )

\begin{tabular}{|c|c|c|c|c|c|c|}
\hline \multirow[t]{2}{*}{ Item } & \multicolumn{3}{|c|}{ Live body weight (g) at } & \multicolumn{3}{|c|}{ Daily gain (g/day) at } \\
\hline & $\mathbf{0 ~ W}$ & $4 \mathrm{~W}$ & $8 \mathrm{~W}$ & $0-4 \mathrm{~W}$ & 4-8 W & $0-8 \mathrm{~W}$ \\
\hline$\overline{\mathrm{T1}}$ & $530.67 \pm 14$ & $0.33 \pm 16$. & $2031.33 \pm 50.09^{f}$ & $27.13 \pm 0.71^{d}$ & $26.47 \pm 1.55^{\mathrm{f}}$ & $26.80 \pm 0.83^{\mathrm{e}}$ \\
\hline $\mathbf{T 2}$ & $544.17 \pm 23$ & $.83 \pm 18$ & ${ }^{b c} 2762.00 \pm 58.28^{\mathrm{ab}}$ & ${ }^{b} 36.10 \pm 0.82^{b}$ & $43.12 \pm 2.18^{\mathrm{a}}$ & $39.61 \pm 1.18^{\mathrm{a}}$ \\
\hline T3 & $519.17 \pm 21$ & $.00 \pm 24$. & ${ }^{\mathrm{ab}} 2662.67 \pm 66.72^{\mathrm{bc}}$ & ${ }^{\mathrm{c}} 39.14 \pm 1.36^{\mathrm{ab}}$ & $37.42 \pm 1.71^{\mathrm{bcd}}$ & $38.28 \pm 1.31^{\mathrm{ab}}$ \\
\hline T4 & $541.83 \pm 23$ & $2.33 \pm 21$ & ${ }^{\mathrm{b}} 2665.17 \pm 45.29^{\mathrm{bc}}$ & ${ }^{c} 37.16 \pm 0.88^{\mathrm{ab}}$ & $38.67 \pm 2.00^{\mathrm{abc}}$ & $37.92 \pm 0.60^{\mathrm{ab}}$ \\
\hline T5 & $555.83 \pm 18$ & $2.83 \pm 19$ & $2411.83 \pm 45.94^{\mathrm{de}}$ & ${ }^{\mathrm{e}} 37.75 \pm 0.92^{\mathrm{ab}}$ & $28.54 \pm 1.32^{\mathrm{ef}}$ & $33.14 \pm 1.01^{\mathrm{cd}}$ \\
\hline T6 & $567.00 \pm 29$ & $8.17 \pm 33$ & $4^{\mathrm{a}} 2840.33 \pm 56.27^{\mathrm{a}}$ & $39.33 \pm 1.36^{\mathrm{a}}$ & $41.86 \pm 2.37^{\mathrm{ab}}$ & $40.60 \pm 0.73^{\mathrm{a}}$ \\
\hline $\mathbf{T} 7$ & $566.50 \pm 18$ & $.50 \pm 19$. & ${ }^{\mathrm{ab}} 2556.00 \pm 38.57^{\mathrm{cd}}$ & ${ }^{d} 37.64 \pm 0.33^{\mathrm{ab}}$ & $33.41 \pm 1.48^{\text {cde }}$ & $35.53 \pm 0.70^{\mathrm{bc}}$ \\
\hline Significance & NS & $* * *$ & $* * *$ & $* * *$ & $* * *$ & $* * *$ \\
\hline
\end{tabular}

$\mathrm{NS}=$ Not significance and $* * *=\mathrm{P}<0.001$.

Means in the same column with different letters differ significantly $(\mathrm{P}<0.05)$.

T1 control group, T2 received $250 \mathrm{mg} \mathrm{Cu} / \mathrm{kg}$ diet, T 3 received $500 \mathrm{mg} \mathrm{Cu} / \mathrm{kg}$ diet, T4 received $20 \mathrm{mg} \mathrm{Zn} \mathrm{from}$ Zinc EDTA $+250 \mathrm{mg} \mathrm{Cu} / \mathrm{kg}$ diet, T5 received $20 \mathrm{mg} \mathrm{Zn}$ from Zinc EDTA $+500 \mathrm{mg} \mathrm{Cu} / \mathrm{kg}$ diet, T6 received $20 \mathrm{mg} \mathrm{Zn}$ from $\mathrm{ZnO}+250 \mathrm{mg} \mathrm{Cu} / \mathrm{kg}$ diet and $\mathrm{T} 7$ received $20 \mathrm{mg} \mathrm{Zn}$ from $\mathrm{ZnO}+500 \mathrm{mg} \mathrm{Cu} / \mathrm{kg}$ diet.

supplemented with $20 \mathrm{mg}$ zinc as zinc oxide and supplemented with $250 \mathrm{mg}$ copper recorded higher growth rate than the other experimental groups, then followed by group fed diet supplemented with $250 \mathrm{mg} \mathrm{Cu} / \mathrm{kg}$ diet, then group fed diet supplemented with $500 \mathrm{mg} \mathrm{Cu} / \mathrm{kg}$ diet and this fed diet supplemented with $20 \mathrm{mg}$ $\mathrm{Zn}$ from Zinc EDTA and $250 \mathrm{mg} \mathrm{Cu} / \mathrm{kg}$ diet. Adu and Egbunike (2009) reported that copper supplemented rabbits had a positive improvement in final live weight. The synergistic effect of $\mathrm{Zn}$ and $\mathrm{Cu}$ supplementation was predicted because of their vital roles.

The mechanism by which high levels of copper and zinc improve growth rate in rabbits is still unclear. Both have some antibacterial properties (Dupont et al., 1994), which may explain the growth-promoting effect, but there is a lack of scientific evidence to understand the exact mode of action. The improvement in growth performance when the diet is supplemented with high levels of dietary copper is similar in magnitude to that achieved when infeed antimicrobials are fed to nursery animals. Even though copper has antibacterial properties, growth rate is stimulated in an additive manner when both antimicrobials and high levels of copper are added to nursery animal diets (Cromwell, 2001). Thus, it appears that the growth-promoting properties of high dietary levels of copper are in addition to its antimicrobial effect.

Daily feed intake follows the same trend as in final body weight. Since, daily feed intake was significantly $(\mathrm{P}<0.001)$ increased in rabbit groups treated with $\mathrm{Zn}$ and $\mathrm{Cu}$ (Table 2). Rabbits group fed diets supplemented with 20 $\mathrm{mg} \mathrm{Zn}$ from $\mathrm{ZnO}$ and $500 \mathrm{mg} \mathrm{Cu} / \mathrm{kg}$ diet recorded higher feed intake, then followed by the rabbit group fed diet supplemented with 20 $\mathrm{mg} \mathrm{Zn}$ from Zinc EDTA and $500 \mathrm{mg} \mathrm{Cu} / \mathrm{kg}$ diet, then group fed diet supplemented with $20 \mathrm{mg} \mathrm{Zn}$ from $\mathrm{ZnO}$ and $250 \mathrm{mg} \mathrm{Cu} / \mathrm{kg}$ diet. Also, $\mathrm{Cu}$ supplementations at 250 or $500 \mathrm{mg} / \mathrm{kg}$ diet enhanced daily feed intake comparing to control group, with no significant differences between the two $\mathrm{Cu}$ tested levels. While, Ayyat and Marai (2000) and Selim et al. (2012) found no effect on feed intake of rabbits fed diets supplemented with Zn.

Feed conversion ratio was significantly $(\mathrm{P}<0.001)$ improved in rabbit groups treated with $\mathrm{Zn}$ and $\mathrm{Cu}$ (Table 2). In general, tested supplementations reduced ratio of daily feed 
Zagazig J. Agric. Res., Vol. 45 No. (1) 2018

Table 2. Feed intake and conversion of New Zealand White male rabbits as affected by zinc and copper supplementation (Mean $\pm \mathrm{SE}$ )

\begin{tabular}{lcccccc}
\hline Item & \multicolumn{3}{c}{ Daily feed intake $(g)$ at } & \multicolumn{3}{c}{ Feed conversion (g food/g gain) at } \\
\cline { 2 - 3 } & $\mathbf{0 - 4} \mathbf{~ W}$ & $\mathbf{4 - 8} \mathbf{~ W}$ & $\mathbf{0 - 8} \mathbf{~ W z}$ & $\mathbf{0 - 4} \mathbf{~ W}$ & $\mathbf{4 - 8} \mathbf{~ W}$ & $\mathbf{0 - 8} \mathbf{~ W}$ \\
\hline T1 & $89.74 \pm 0.52^{\mathrm{d}}$ & $117.89 \pm 2.43^{\mathrm{c}}$ & $103.82 \pm 1.28^{\mathrm{d}}$ & $3.32 \pm 0.08^{\mathrm{a}}$ & $4.54 \pm 0.30^{\mathrm{a}}$ & $3.90 \pm 0.14^{\mathrm{a}}$ \\
T2 & $99.14 \pm 1.94^{\mathrm{bcd}}$ & $129.16 \pm 1.89^{\mathrm{ab}}$ & $114.15 \pm 1.61^{\mathrm{bc}}$ & $2.75 \pm 0.07^{\text {cde }}$ & $3.04 \pm 0.16^{\mathrm{d}}$ & $2.89 \pm 0.08^{\mathrm{e}}$ \\
T3 & $106.46 \pm 5.22^{\mathrm{abc}}$ & $122.08 \pm 2.84^{\mathrm{bc}}$ & $114.27 \pm 3.19^{\mathrm{bc}}$ & $2.72 \pm 0.08 \mathrm{~d}^{\mathrm{e}}$ & $3.29 \pm 0.14^{\mathrm{cd}}$ & $2.99 \pm 0.07^{\mathrm{de}}$ \\
T4 & $97.49 \pm 2.40^{\mathrm{bcd}}$ & $124.87 \pm 2.16^{\mathrm{bc}}$ & $111.18 \pm 1.76^{\mathrm{c}}$ & $2.63 \pm 0.10^{\mathrm{e}}$ & $3.27 \pm 0.18^{\mathrm{cd}}$ & $2.93 \pm 0.05^{\mathrm{e}}$ \\
T5 & $114.13 \pm 2.85^{\mathrm{a}}$ & $126.68 \pm 2.75^{\mathrm{b}}$ & $120.41 \pm 0.90^{\mathrm{ab}}$ & $3.04 \pm 0.11^{\mathrm{abcd}}$ & $4.47 \pm 0.14^{\mathrm{a}}$ & $3.65 \pm 0.11^{\mathrm{ab}}$ \\
T6 & $108.69 \pm 6.36^{\mathrm{ab}}$ & $124.77 \pm 0.94^{\mathrm{bc}}$ & $116.74 \pm 3.44^{\mathrm{bc}}$ & $2.80 \pm 0.23^{\text {cde }}$ & $3.03 \pm 0.17^{\mathrm{d}}$ & $2.88 \pm 0.08^{\mathrm{e}}$ \\
T7 & $117.18 \pm 3.85^{\mathrm{a}}$ & $135.38 \pm 3.08^{\mathrm{a}}$ & $126.28 \pm 3.28^{\mathrm{a}}$ & $3.12 \pm 0.11^{\mathrm{abc}}$ & $4.10 \pm 0.25^{\mathrm{ab}}$ & $3.57 \pm 0.14^{\mathrm{b}}$ \\
Significance & $* * *$ & $* * *$ & $* * *$ & $* *$ & $* * *$ & $* * *$ \\
\hline
\end{tabular}

$\mathrm{NS}=$ Not significance, ${ }^{* *} \mathrm{P}<0.01$ and $* * *=\mathrm{P}<0.001$.

Means in the same column with different letters differ significantly $(\mathrm{P}<0.05)$.

$\mathrm{T} 1$ control group, T2 received $250 \mathrm{mg} \mathrm{Cu} / \mathrm{kg}$ diet, T 3 received $500 \mathrm{mg} \mathrm{Cu} / \mathrm{kg}$ diet, T4 received $20 \mathrm{mg} \mathrm{Zn}$ from Zinc EDTA + $250 \mathrm{mg} \mathrm{Cu} / \mathrm{kg}$ diet, T5 received $20 \mathrm{mg}$ Zn from Zinc EDTA $+500 \mathrm{mg} \mathrm{Cu} / \mathrm{kg}$ diet, T6 received 20 $\mathrm{mg} \mathrm{Zn}$ from $\mathrm{ZnO}+250 \mathrm{mg} \mathrm{Cu} / \mathrm{kg}$ diet and $\mathrm{T} 7$ received $20 \mathrm{mg} \mathrm{Zn}$ from $\mathrm{ZnO}+500 \mathrm{mg} \mathrm{Cu} / \mathrm{kg}$ diet.

intake related to daily weight gain. Rabbits fed diet supplemented with $20 \mathrm{mg} \mathrm{Zn}$ from $\mathrm{ZnO}$ and $250 \mathrm{mg} \mathrm{Cu} / \mathrm{kg}$ diet recorded the best feed conversion. Feed conversion improved to 26.15 , $25.90,24.87,23.33,8.46$ and $6.41 \%$, respectively in rabbit groups fed diet supplemented with $20 \mathrm{mg} \mathrm{Zn}$ from $\mathrm{ZnO}$ and 250 $\mathrm{mg} \mathrm{Cu} / \mathrm{kg}$ diet (T6), rabbits fed diet supplemented with $250 \mathrm{mg} \mathrm{Cu} / \mathrm{kg}$ diet (T2), rabbits fed diet supplemented with $20 \mathrm{mg} \mathrm{Zn}$ from Zinc EDTA and $250 \mathrm{mg} \mathrm{Cu} / \mathrm{kg} \operatorname{diet}(\mathrm{T} 4)$, rabbits fed diet supplemented with $500 \mathrm{mg}$ $\mathrm{Cu} / \mathrm{kg}$ diet (T3), rabbits fed diet supplemented with $20 \mathrm{mg} \mathrm{Zn}$ from $\mathrm{ZnO}$ and $500 \mathrm{mg} \mathrm{Cu} / \mathrm{kg}$ diet (T7) and rabbits fed diet supplemented with $20 \mathrm{mg} \mathrm{Zn}$ from Zinc EDTA and $500 \mathrm{mg} \mathrm{Cu} / \mathrm{kg}$ diet (T5). Selim et al. (2012) reported improvements in feed conversion ratio in rabbits fed $\mathrm{Zn}$ supplemented diet at levels of 50, 100 or $200 \mathrm{mg} / \mathrm{kg}$ diet.

The immune modulator and antimicrobial properties of $\mathrm{Zn}$ and $\mathrm{Cu}$ have been extensively studied. Both $\mathrm{Zn}$ and $\mathrm{Cu}$ are claimed to provide protection against infectious diseases in vivo, and to regulate innate immune response (Stafford et al., 2013). However, it is known that the redistribution of $\mathrm{Zn}$ in the organism following an inflammatory stimulus follow a specific strategy; while plasma $\mathrm{Zn}$ decreases, liver, thymus, and bone marrow accumulate $\mathrm{Zn}$ (Cousins and Leinart, 1988). Among the wellknown functions of $\mathrm{Zn}$ and $\mathrm{Cu}$, their role in the defense against free radical has been extensively studied. It has been shown above that reduced serum levels of $\mathrm{Zn}$ with advancing aging might also occur, independently of a decrease in serum albumin, by dislocation of $\mathrm{Zn}$ from the serum albumin pool and its subsequent delivery in the free or labile form into other compartments. Interestingly, a different role for cellular function of $\mathrm{Zn}$ in the free or labile form than in the $\mathrm{Zn}-\mathrm{Alb}$ ones has been observed. Indeed, the quota of free or labile $\mathrm{Zn}$ seems to be mostly involved in the oxidative stress response (Maret, 2006 ; Putics et al., 2008) by modulating the mechanisms of resistance to apoptosis (Thambiayya et al., 2012), immune function (Haase and Rink, 2014), as well as in the production of specific antioxidant proteins (Liuzzi et al., 2005).

\section{Blood Analyses}

Results of Table 3 revealed that comparing to control group, all tested diet supplementations had no significant effect on concentrations of albumin and cholesterol and activity of ALT 
Helal, et al.

Table 3. Blood analysis of growing rabbits as affected by zinc and copper supplementation $($ Mean \pm SE)

\begin{tabular}{lccccccc}
\hline Item & $\begin{array}{c}\text { Total } \\
\text { protein }\end{array}$ & Albumin & Cholesterol & ALT & AST & Urea & Creatinine \\
\hline T1 & $6.01 \pm 0.12^{\mathrm{b}}$ & $3.770 \pm 0.17$ & $91.04 \pm 4.78$ & $51.62 \pm 6.20$ & $48.07 \pm 4.71$ & $18.89 \pm 0.85^{\mathrm{c}}$ & $0.475 \pm 0.03^{\mathrm{b}}$ \\
T2 & $6.600 \pm 0.09^{\mathrm{ab}}$ & $4.075 \pm 0.12$ & $99.67 \pm 2.45$ & $47.58 \pm 13.99$ & $44.92 \pm 9.23$ & $28.59 \pm 0.82^{\mathrm{ab}}$ & $0.530 \pm 0.03^{\mathrm{ab}}$ \\
T3 & $6.640 \pm .18^{\mathrm{ab}}$ & $4.340 \pm 0.04$ & $137.79 \pm 19.32$ & $33.36 \pm 2.28$ & $29.32 \pm 1.99$ & $30.43 \pm 2.14^{\mathrm{a}}$ & $0.470 \pm 0.01^{\mathrm{b}}$ \\
T4 & $7.050 \pm 0.10^{\mathrm{ab}} 3.370 \pm 0.14$ & $88.22 \pm 5.22$ & $23.10 \pm 3.30$ & $30.23 \pm 2.83$ & $\begin{array}{c}21.29 \pm 1.73^{\mathrm{ab}} \\
{ }^{\mathrm{a}}\end{array}$ & $0.456 \pm 0.04^{\mathrm{b}}$ \\
T5 & $7.315 \pm 0.13^{\mathrm{a}}$ & $3.996 \pm 0.09$ & $112.31 \pm 4.61$ & $36.10 \pm 0.83$ & $36.69 \pm 2.61$ & $17.31 \pm 1.30^{\mathrm{c}}$ & $0.660 \pm 0.02^{\mathrm{a}}$ \\
T6 & $6.560 \pm 0.32^{\mathrm{ab}} 3.606 \pm 0.35$ & $118.58 \pm 9.73$ & $47.06 \pm 1.70$ & $38.89 \pm 0.64$ & $19.76 \pm 1.74^{\mathrm{bc}}$ & $0.666 \pm 0.03^{\mathrm{a}}$ \\
T7 & $6.380 \pm 0.28^{\mathrm{ab}} 4.256 \pm 0.15$ & $123.78 \pm 9.39$ & $31.07 \pm 2.93$ & $25.50 \pm 2.60$ & $25.14 \pm 1.6^{\mathrm{abc}}$ & $0.570 \pm 0.03^{\mathrm{ab}}$ \\
Significance & $* *$ & $\mathrm{NS}$ & $\mathrm{NS}$ & $\mathrm{NS}$ & $\mathrm{NS}$ & $* * *$ & $* * *$ \\
\hline
\end{tabular}

NS $=$ Not significance, ${ }^{* *} \mathrm{P}<0.01$ and $* * *=\mathrm{P}<0.001$.

Means in the same column with different letters differ significantly $(\mathrm{P}<0.05)$.

$\mathrm{T} 1$ control group, T2 received $250 \mathrm{mg} \mathrm{Cu} / \mathrm{kg}$ diet, T 3 received $500 \mathrm{mg} \mathrm{Cu} / \mathrm{kg}$ diet, T4 received $20 \mathrm{mg} \mathrm{Zn} \mathrm{from}$ Zinc EDTA $+250 \mathrm{mg} \mathrm{Cu} / \mathrm{kg}$ diet, T5 received $20 \mathrm{mg} \mathrm{Zn} \mathrm{from} \mathrm{Zinc} \mathrm{EDTA}+500 \mathrm{mg} \mathrm{Cu} / \mathrm{kg}$ diet, T6 received 20 $\mathrm{mg} \mathrm{Zn}$ from $\mathrm{ZnO}+250 \mathrm{mg} \mathrm{Cu} / \mathrm{kg}$ diet and $\mathrm{T} 7$ received $20 \mathrm{mg} \mathrm{Zn}$ from $\mathrm{ZnO}+500 \mathrm{mg} \mathrm{Cu} / \mathrm{kg}$ diet.

(alanine aminotransferase) and AST (aspartate aminotransferase), while concentrations of total protein, urea and creatinine were significantly affected. Total protein concentration significantly $(\mathrm{P}<0.01)$ increased in blood of rabbits group fed $20 \mathrm{mg} \mathrm{Zn}$ from Zn EDTA + $500 \mathrm{mg} \mathrm{Cu} / \mathrm{kg}$ diet (T5), other supplementation treatments did not significantly differ comparing to control. Significant $(\mathrm{P}<0.001)$ increases were noticed respecting urea concentration in rabbits fed $\mathrm{Cu}$ supplemented feed at 250 (T2) or 500 (T3) $\mathrm{mg} / \mathrm{kg}$. also, createnine concentration was significantly $(\mathrm{P}<0.001)$ increased in rabbits fed $20 \mathrm{ppm} \mathrm{Zn}$ from Zinc EDTA $+500 \mathrm{mg} \mathrm{Cu} / \mathrm{kg}$ diet (T5) or $20 \mathrm{ppm} \mathrm{Zn}$ from $\mathrm{Zinc} \mathrm{ZnO}+250$ $\mathrm{mg} \mathrm{Cu} / \mathrm{kg}$ diet (T6) comparing to control.

\section{Carcass Components}

Rabbits fed the tested supplementation diet treatments exhibited significant $(\mathrm{P}<0.05)$ increases in pre-slaughter weight (Table 4) as compared to control group. The highest increases in this regard were recorded under the effect of T2 (250 mg Cu/ kg diet) and T6 (20 mg $\mathrm{Zn}$ from $\mathrm{ZnO}+250 \mathrm{mg} \mathrm{Cu} / \mathrm{kg}$ diet) compared to other supplementation treatments. As mentioned above, these treatments also recorded the highest increases in daily body weight gain and final live body weight at the end of the experimental feeding period (Table 1) and also favored feed conversion ratio (Table 2).

Weights of carcass, liver and kidney and weights of head and hind part (Tables 4 and 5) were not significantly affected with the tested supplementation treatments. However, Selim et al. (2012) reported that dressing (\%) was not significantly affected with $\mathrm{Zn}$ supplementation at levels of 50,100 or $200 \mathrm{mg} \mathrm{kg}^{-1}$ diet, but liver and kidney weights (as \% of live weight) were increased with $\mathrm{Zn}$ supplementation at levels of 50,100 or $200 \mathrm{mg} / \mathrm{kg}$ diet compared to rabbits fed with no $\mathrm{Zn}$ supplementation or those fed with high level of $400 \mathrm{mg} / \mathrm{kg}$ diet.

\section{Economic Efficiency}

Feed cost and income from gain per rabbit as well as final margin were increased in all rabbits fed supplemented feed (Table 6). The highest income from gain was recorded in rabbit groups affected with $\mathrm{T} 2$ and $\mathrm{T} 6$ comparing to other supplementation treatments, and this in turn reflected as the highest final margin. 
Zagazig J. Agric. Res., Vol. 45 No. (1) 2018

Table 4. Actual pre-slaughter live weight and adjusted carcass, liver and kidney weight of growing rabbits as affected by zinc and copper supplementation (Mean $\pm \mathrm{SE}$ )

\begin{tabular}{lccccc}
\hline Item & $\begin{array}{c}\text { Pre-slaughter weight Carcass weight } \\
(\mathbf{g})\end{array}$ & $\begin{array}{c}\text { Dressing } \\
(\mathbf{9})\end{array}$ & $\begin{array}{c}\text { Liver weight Kidney weight } \\
(\mathbf{g})\end{array}$ & $(\mathbf{g})$ \\
\hline T1 & $2131.0 \pm 26.3^{\mathrm{e}}$ & $1735.88 \pm 238.6$ & $59.51 \pm 2.40$ & $81.19 \pm 23.24$ & $18.74 \pm 5.23$ \\
T2 & $2873.3 \pm 17.6^{\mathrm{a}}$ & $1814.76 \pm 104.58$ & $69.59 \pm 0.43$ & $79.37 \pm 10.19$ & $20.43 \pm 2.29$ \\
T3 & $2778.0 \pm 49.6^{\mathrm{b}}$ & $1773.05 \pm 70.40$ & $67.47 \pm 0.28$ & $72.93 \pm 6.86$ & $22.79 \pm 1.54$ \\
T4 & $2754.3 \pm 31.1^{\mathrm{b}}$ & $1794.14 \pm 63.36$ & $68.02 \pm 2.33$ & $67.82 \pm 6.17$ & $20.52 \pm 1.39$ \\
T5 & $2508.3 \pm 16.4^{\mathrm{d}}$ & $1790.91 \pm 83.71$ & $65.97 \pm 1.92$ & $63.18 \pm 8.15$ & $19.10 \pm 1.83$ \\
T6 & $2956.7 \pm 33.8^{\mathrm{a}}$ & $1779.99 \pm 137.97$ & $68.92 \pm 1.08$ & $69.22 \pm 13.44$ & $18.48 \pm 3.02$ \\
T7 & $2638.7 \pm 19.9^{\mathrm{c}}$ & $1739.26 \pm 50.16$ & $65.15 \pm 2.83$ & $76.01 \pm 4.89$ & $18.79 \pm 1.10$ \\
Significance & $*$ & $\mathrm{NS}$ & $\mathrm{NS}$ & $\mathrm{NS}$ & $\mathrm{NS}$ \\
LW- Significance & ------ & $\mathrm{NS}$ & $\mathrm{NS}$ & $\mathrm{NS}$ & $\mathrm{NS}$ \\
\hline
\end{tabular}

LW- Significance $=$ Regression on pre-slaughter weight.

* $\mathrm{P}<0.05$ and $\mathrm{NS}=$ Not significant.

Means in the same column within each classification with different letters differ significantly $(\mathrm{P}<0.05)$.

$\mathrm{T} 1$ control group, T2 received $250 \mathrm{mg} \mathrm{Cu} / \mathrm{kg}$ diet, T 3 received $500 \mathrm{mg} \mathrm{Cu} / \mathrm{kg}$ diet, T4 received $20 \mathrm{mg} \mathrm{Zn} \mathrm{from}$ Zinc EDTA + $250 \mathrm{mg} \mathrm{Cu} / \mathrm{kg}$ diet, T5 received $20 \mathrm{mg} \mathrm{Zn} \mathrm{from} \mathrm{Zinc} \mathrm{EDTA}+500 \mathrm{mg} \mathrm{Cu} / \mathrm{kg}$ diet, T6 received 20 $\mathrm{mg} \mathrm{Zn}$ from $\mathrm{ZnO}+250 \mathrm{mg} \mathrm{Cu} / \mathrm{kg}$ diet and $\mathrm{T} 7$ received $20 \mathrm{mg} \mathrm{Zn}$ from $\mathrm{ZnO}+500 \mathrm{mg} \mathrm{Cu} / \mathrm{kg}$ diet.

Table 5. Adjusted carcass components of growing rabbits as affected by zinc and copper supplementation (Mean $\pm \mathrm{SE})$

\begin{tabular}{lcccc}
\hline Item & $\begin{array}{c}\text { Head weight } \\
(\mathbf{g})\end{array}$ & $\begin{array}{c}\text { Fore part weight } \\
(\mathbf{g})\end{array}$ & $\begin{array}{c}\text { Intermediate weight } \\
(\mathbf{g})\end{array}$ & $\begin{array}{c}\text { Hind part weight } \\
(\mathbf{g})\end{array}$ \\
\hline T1 & $108.27 \pm 13.27$ & $497.26 \pm 75.31$ & $509.63 \pm 81.23$ & $296.01 \pm 93.65$ \\
T2 & $141.49 \pm 5.82$ & $445.56 \pm 33.01$ & $424.45 \pm 35.60$ & $349.41 \pm 41.05$ \\
T3 & $137.88 \pm 3.91$ & $473.26 \pm 22.22$ & $475.94 \pm 23.97$ & $316.80 \pm 27.63$ \\
T4 & $130.82 \pm 3.52$ & $459.30 \pm 19.99$ & $423.34 \pm 21.57$ & $352.97 \pm 24.87$ \\
T5 & $128.90 \pm 4.66$ & $524.83 \pm 26.42$ & $508.19 \pm 28.50$ & $306.48 \pm 32.86$ \\
T6 & $139.39 \pm 7.67$ & $396.59 \pm 43.54$ & $358.21 \pm 46.97$ & $333.12 \pm 54.15$ \\
T7 & $129.59 \pm 2.79$ & $490.86 \pm 15.83$ & $461.24 \pm 17.08$ & $332.22 \pm 19.69$ \\
Significance & NS & $*$ & $*$ & NS \\
LW- Significance & NS & NS & NS & NS \\
\hline
\end{tabular}

LW- Significance $=$ Regression on pre-slaughter weight.

* $\mathrm{P}<0.05$ and $\mathrm{NS}=$ Not significant.

Means in the same column within each classification with different letters differ significantly $(\mathrm{P}<0.05)$.

T1 control group, T2 received $250 \mathrm{mg} \mathrm{Cu} / \mathrm{kg}$ diet, T 3 received $500 \mathrm{mg} \mathrm{Cu} / \mathrm{kg}$ diet, T4 received $20 \mathrm{mg} \mathrm{Zn} \mathrm{from}$ Zinc EDTA $+250 \mathrm{mg} \mathrm{Cu} / \mathrm{kg}$ diet, T5 received $20 \mathrm{mg} \mathrm{Zn}$ from Zinc EDTA $+500 \mathrm{mg} \mathrm{Cu} / \mathrm{kg}$ diet, T6 received 20 $\mathrm{mg} \mathrm{Zn}$ from $\mathrm{ZnO}+250 \mathrm{mg} \mathrm{Cu} / \mathrm{kg}$ diet and $\mathrm{T} 7$ received $20 \mathrm{mg} \mathrm{Zn}$ from $\mathrm{ZnO}+500 \mathrm{mg} \mathrm{Cu} / \mathrm{kg}$ diet. 
Helal, et al.

Table 6. Profit analysis of growing rabbits as affected by zinc and copper supplementation

\begin{tabular}{lccc}
\hline Item & $\begin{array}{c}\text { Feed cost } \\
\text { (LE/rabbit) }\end{array}$ & $\begin{array}{c}\text { Return from gain } \\
\text { (LE/ rabbit) }\end{array}$ & $\begin{array}{c}\text { Margin } \\
\text { (LE/ rabbit) }\end{array}$ \\
\hline T1 & 17.441 & 54.837 & 37.396 \\
T2 & 20.295 & 74.574 & 54.279 \\
T3 & 21.443 & 71.874 & 50.431 \\
T4 & 19.892 & 71.955 & 52.063 \\
T5 & 22.730 & 65.097 & 42.367 \\
T6 & 20.773 & 76.68 & 55.907 \\
T7 & 23.715 & 69.012 & 45.297
\end{tabular}

T1 control group, $\mathrm{T} 2$ received $250 \mathrm{mg} \mathrm{Cu} / \mathrm{kg}$ diet, $\mathrm{T} 3$ received $500 \mathrm{mg} \mathrm{Cu} / \mathrm{kg}$ diet, T4 received $20 \mathrm{mg} \mathrm{Zn}$ from Zinc EDTA $+250 \mathrm{mg} \mathrm{Cu} / \mathrm{kg}$ diet, T5 received $20 \mathrm{mg} \mathrm{Zn} \mathrm{from} \mathrm{Zinc} \mathrm{EDTA}+500 \mathrm{mg} \mathrm{Cu} / \mathrm{kg}$ diet, T6 received 20 $\mathrm{mg} \mathrm{Zn}$ from $\mathrm{ZnO}+250 \mathrm{mg} \mathrm{Cu} / \mathrm{kg}$ diet and $\mathrm{T} 7$ received $20 \mathrm{mg} \mathrm{Zn}$ from $\mathrm{ZnO}+500 \mathrm{mg} \mathrm{Cu} / \mathrm{kg}$ diet.

\section{REFERENCES}

Adu, O.A. and G.N. Egbunike (2009). Enhancing growing rabbits performance with diets supplemented with copper. Adv. Biol. Res., 3 (5-6): 179-184.

Aksu, D.S., T. Aksu and S.E. Onel (2012). Does inclusion at low levels of organically complexed minerals versus inorganic forms create a weakness in performance or antioxidant defense system in broiler diets? Int. J. Poult. Sci., 11: 666- 672.

Ayyat, M.S. (1991). Growth and carcass production of growing rabbits as affected by dietary energy level. Zagazig J. Agric. Res., 18 (1): 109-122.

Ayyat, M.S. and I.F. Marai (2000). Growth performance and carcass traits as affected by breed and dietary supplementation with different zinc levels, under Egyptian condition. In: $7^{\text {th }}$ World rabbit Cong, Spain, p. $83-88$.

Cobine, P.A., F. Pierrel and D.R. Winge (2006). Copper trafficking to the mitochondrion and assembly of copper metalloenzymes. Biochimica et Biophysica Acta (BBA) Molecular Cell Res., 1763 (7): 759-772.

Cousins, R.J. and A.S. Leinart (1988). Tissuespecific regulation of zinc metabolism and metallothionein genes by interleukin.
Federation of Ame. Soc. for Exp. Biol. J., 2: 2884-2890.

Cromwell, G.L. (2001). Antimicrobial and promicrobial agents. In: Lewis AJ, Southern LL, Eds. Swine Nutrition. 2 ${ }^{\text {nd }}$ Ed. Boca Raton, Florida: CRC Press, 401-426.

Dupont, D.P., G.E. Duhamel, M.P. Carlson, and M.R. Mathiesen (1994). Effect of divalent cations on hemolysin synthesis by Serpulina (Treponema) hyodysenteriae: inhibition induced by zinc and copper. Vet. Microbiol., 41: 63-73.

Duncan, D.B. (1955). Multiple Range and Multiple F-test. Biom., 11: 1-42.

Festa, R.A. and D.J. Thiel (2011). Copper: An essential metal in biology. Current Biol., 21 (21): 877-883.

Haase, H. and L. Rink (2014). Zinc signals and immune function. BioFactors, 40: 27-40.

Ladomersky, E. and M.J. Petris (2015). Copper tolerance and virulence in bacteria. Metallomics, 7 (6): 957-964.

Liuzzi, J.P., L.A. Lichten, S. Rivera, R.K. Blanchard, T.B. Aydemir, M.D. Knutson, T. Ganz and R.J. Cousins (2005). Interleukin-6 regulates the zinc transporter Zip14 in liver and contributes to the hypozincemia of the acute-phase response. Proc. Nat. Acad. Sci. United States of Ame., 102: 6843-6848. 
Maret, W. (2006). Zinc coordination environments in proteins as redox sensors and signal transducers. Antioxidants and Redox Signaling J., 8: 1419-1441.

McDonald, R.S. (2000). The role of zinc in growth and cell proliferation. J. Nutr., 130: 1500-1508.

Putics, A., D. Vödrös, M. Malavolta, E. Mocchegiani, P. Csermely and C. Soti (2008). Zinc supplementation boosts the stress response in the elderly: Hsp70 status is linked to zinc availability in peripheral lymphocytes. Exp. Gerontol. J., 43: 452-461.

Selim, N., A.M. Abdel-Khalek and S.M. Gad (2012). Effect of supplemental zinc, magnesium or iron on performance and some physiological traits of growing rabbits. Asian J. Poult. Sci., 6: 23-30.

Sendovski, M., M. Kanteev, V.S. Ben-Yosef, N. Adir and A. Fishman (2011). First structures of an active bacterial tyrosinase reveal copper plasticity. J. Molec. Biol., 405: 227237.

Stafford, S.L., N.J. Bokil, M.E. Achard, R. Kapetanovic, M.A. Schembri, A.G. McEwan and M.J. Sweet (2013). Metal ions in macrophage antimicrobial pathways: emerging roles for zinc and copper. Bioscience Reports, $33: 4$.

Terpiłowska, S. and A.K. Siwicki (2011). The role of selected microelements: selenium, zinc, chromium and iron in immune system. Central-Europ. J. Immunol., 36 (4): 303-307.

Thambiayya, K., K. Wasserloos, V.E. Kagan, D. Stoyanovsky and B.R. Pitt (2012). Acritical role for increased labile zinc in reducing sensitivity of cultured sheeppulmonary artery endothelial cells to LPS-induced apoptosis. Ame. J. Physiol. Lung Cellular and Molec. Physiol., 302: 1287-1295.

Thornton, P.K. (2010). Review, Livestock production: recent trends, future prospects. Philosophical Transactions of the Royal Soc. B, 365: 2853-2867.

Wang, B., C. Xu, W. Ge, M.A. Zhang, B. Yue and K. Zhang (2013). Effects of copper on growth performance, slaughter performance, serum oxidase activity and hormone content of wulong geese aged 1 to 4 weeks. Chin. J. Anim. Nutr., 25: 2897-2905.

Xu, Y., X.H. Zhang, and Y.Z. Pang (2013). Association of tyrosinase (TYR) and tyrosinase-related protein 1 (TYRP1) with Melanic Plumage Color in Korean Quails (Coturnix coturnix). Asian Aust. J. Anim. Sci., 26: 1518-1522.

Yatoo, M.I., A. Saxena, P.M. Deepa, B.P. Habeab, S. Devi, R.S. Jatav and U. Dimri (2013) Role of Trace elements in animals: a review, Vet. World, 6 (12): 963-967. 


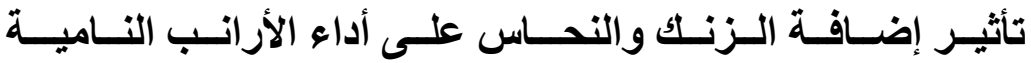

\author{
أميرة عبد المحسن عبد الثافي هلال ـ أسامه محمد عبد المنعم

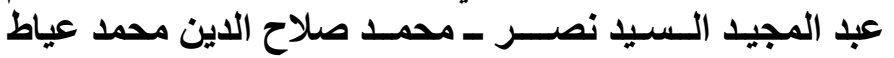

قسم الإنتاج الحيو اني ـ كلية الزراعة - جامعة الزقازيق - مصر

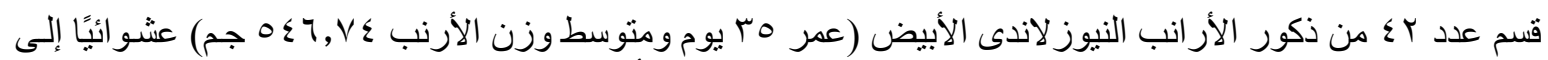

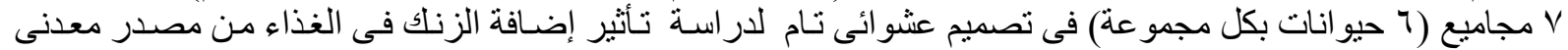

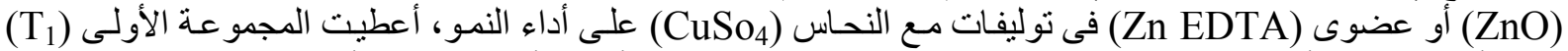

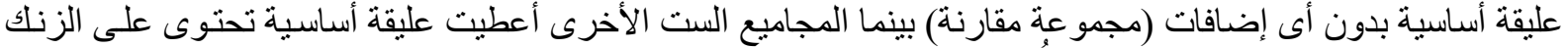

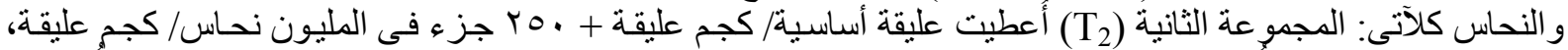

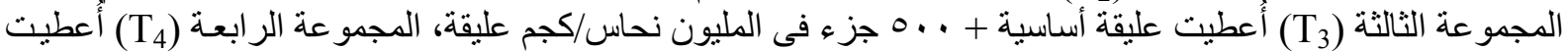

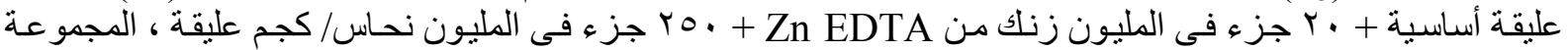

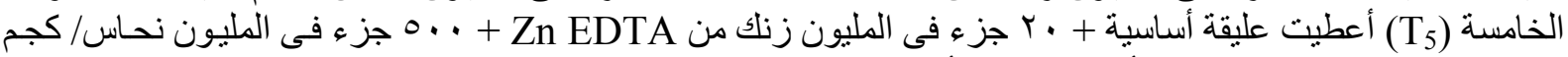

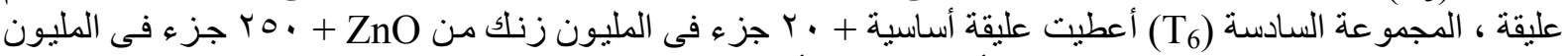

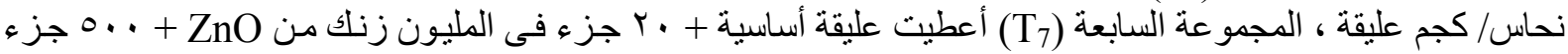

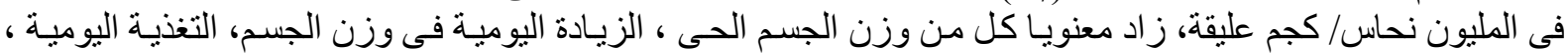

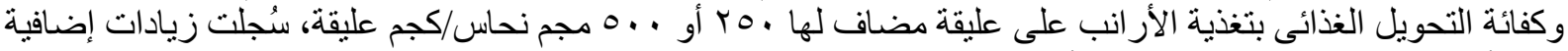

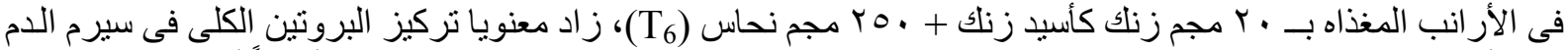

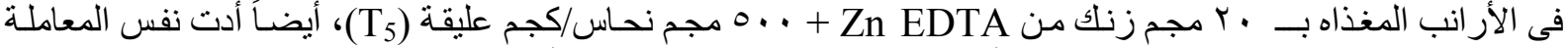

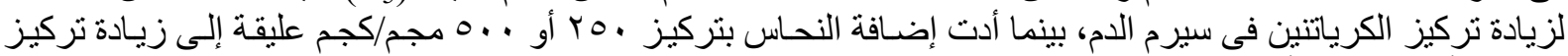

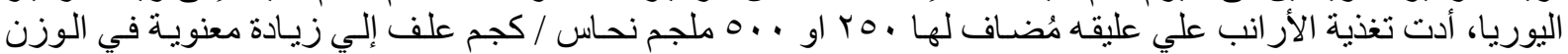

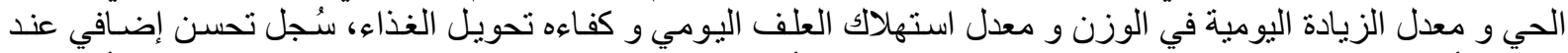

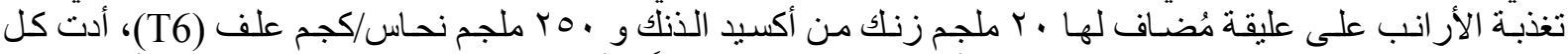

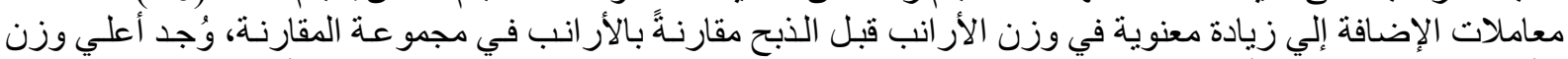

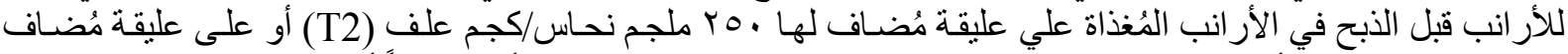

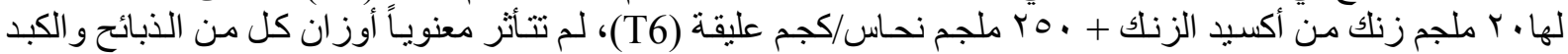

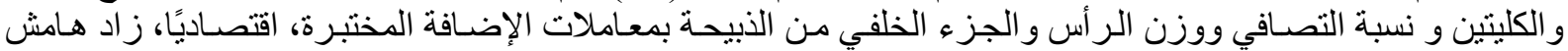

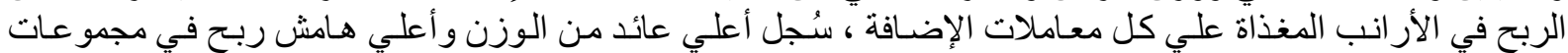

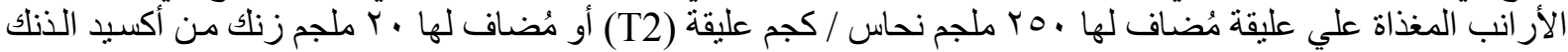

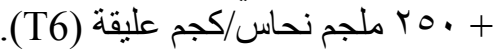

أستاذ فسيولوجي الحيو ان - كلية الزر اعة - جامعة المنصورة. أستاذ فسيولوجي الحيو ان - كلية الزر اعة بالإسماعيليةــ جامعة قناة السويس.

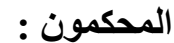

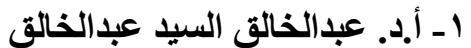

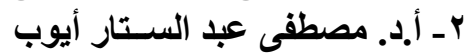

